Василий Сенкевич

ORCID: 0000-0002-6694-2530

Uniwersytet Przyrodniczo-Humanistyczny w Siedlcach Wydział Nauk Humanistycznych

\title{
Гендерная роль и феноменологический статус мужчины (антиномия идентичности и аутентичности)
}

https://doi.org/10.34739/clit.2021.15.01

\section{Gender Role and Phenomenological Status of a Man (Antinomy in Identity and Authenticity)}

The article is devoted to antinomy in gender plan of a man and phenomenological aspect of all that relates to embodiment of the Yang in a language. Contrasting the "real man" concept with the phenomenon of real men, cognitive nature of identity law and phenomenological essence of authenticity principle are revealed. Negative (unmanifested) essence and atomicity of a person's life world and principle of awareness attributed to it are postulated.

Keywords: identity, authenticity, gender role, real man, antipodes

Есть только мужики и бабы, а остальное - фразеология.

(N - российский политик)

\section{Введение}

Закон тождества как сохранение определенности и предметного значения суждений является основным законом классической логики. Не бывает логического мышления и рассуждения без субъекта, подлежащего идентификации: «ибо невозможно ничего мыслить, если не мыслить что-нибудь одно»1. Однако всё не может быть понято, определено и объяснено посредством отношения (равенства/

${ }^{1}$ Аристотель, Метафизика, [в:] Антология мировой философии в 4-х т., т. 1, Москва 1969, c. 457. 
неравенства) и представлено единицей, т.е. «той общей природой, к которой должны быть одинаково приобщены вещи, сравниваемые между собой»². В познании закон тождества $(\mathrm{A}=\mathrm{A})$ дополняется принципом аутентичной негации «не-А» (Всё не то. Всё не так). Отвлечься от предикативного «каза» и вернуться к допредикативной (a priori) реальности - задача настоящей статьи. Её решение осуществляется путем сопоставления свойственной мужчине идентичности и его сущностной характеристики - аутентичности.

\section{1. Закон идентичности. Концепт «настоящий мужчина»}

1.1. Личная идентификаци проявляется как отношение лица к себе, устанавливаемое им самим. Идентифицируя себя, субъект отвечает на вопрос «Кто я такой?» (напр.: $Я$ - <Имярек>, a ты? Кто ты такой?). Речевой формулой выражения собственной идентичности и правовой компетенции в речи является местоимение «Я»: «Тот есть „еgо”, кто произносит „еgо”. Мы находим здесь самое основание „субъективности”, определяемой языковой ролью „лица” 3. Собственное определение возможно в результате позиционирования себя как личности. «Я могу употребить $я$ только при обращении к кому, кто в моем обращении предстает как ты»».4

В актах личного номинирования транслируется пафос и проявляется стратегия деятельности лица. Личная идентификация является формой провозглашения независимости, гарантией безопасности и актом демонстрации собственной значимости (напр.: Civis Romanus sum! - Я римский гражданин!). За «Я» должно стоять собственное имя - закон и инвариант личности. «Когда я, - пишет А.Ф. Лосев, - называю эту бумагу бумагой, а этот диван диваном, то в собственном смысле это не есть ещё именование предмета. Это название вещи. Имя в собственном смысле есть всегда собственное, а не нарицательное имя»5.

Акт личной идентификации относится к онтологии и не обходится без глагола быть, напр.: Я не я буду, если не найду выход из этого положения! (Я. Тройнич, Колдовство для олигарха). Именно

\footnotetext{
2 Р. Декарт, Сочинения в 2 m. Перевод с лат. и франц., сост., ред., вступ. ст. В.В. Соколова, т. 1, Москва 1989, с. 140.

3 Э. Бенвенист, Общая лингвистика, Москва 1974, с. 294.

4 Ibidem, c. 296.

5 А.Ф. Лосев, Бытие - имя - космос, Москва 1993, с. 817.
} 
в быту проявляется динамическая установка на сохранение тождества субъекта как значимой единицы: - Будъте собой. Все остальные места уже заняты (Оскар Уайльд). Просто будъ собой, нет никого лучше (Т. Свифт). - Простота жизни - это бътть собой (Б. Браун). Побудительная фраза Будь собой! направлена на установление положения, обеспечивающего личный комфорт, при котором субъект ощущает себя не индивидом (объектом), а независимой социальнозначимой единицей, т.е. личностью.

Глаголом быть выражается идея существования (existentia). Быть - значит как-то проявляет себя в обстоятельствах, заданных существующими нормативными установками. В институциональной действительности («мире по установлению») существует представление о добре и зле, правильном и должном. Бытие не обходится без универсального утвердительного определения позитивной опоры «так»: быть так (устар.) - выражение согласия; так и быть - пожалуй, пусть будет так (MAC, 1,130-131)6. Любое понятие и определение должно соответствовать критерию точности, напр.: Задача ясна? - Так точно. - Действуйте (В. Катаев, Сын полка). Позитивная природа «так»-бытия выражена, например, в следующем афоризме: Никогда так не бъло, чтоб никак не было. Всегда так было, чтобы как-нибудъ да бълло! (Я. Гашек, Похождения бравого солдата Швейка).

Действительность, в которой все должно чему-то соответствовать или с чем-нибудь согласовываться, является миром ожидания, «в котором я знаю, что будет, или я ожидаю, что если я сделаю так-то, то будет то-то и то-то»7. Существующее в этом мире должно быть фактически засвидетельствовано и верифицировано на предмет истинности: - Тогда дело действительно серъезное, - согласилась девуика. - Еду (В. Шалыгин, Время Зверя). Тогда кровь, разумеется, принадлежит второму лицу - предположительно убийце, если здесь действительно произошло убийство (А. Конан Дойл, Этюд в багровых тонах).

Идея соответствия действительности имеет многообразное выражение в языке. Она связана с представлением о фактической

\footnotetext{
6 Здесь и далее: МАС - Словарь русского языка в 4 m., под ред. А.П. Евгеньевой, Москва 1981-1984.

7 М.К. Мамардашвили, Психологическая топология пути. М. Пруст «В поисках утраченного времени», Санкт-Петербург 1997, с. 45.
} 
данности и настоящести, напр.: Справка Дана, настоящая в том, что студент (ка)... Семантика действительного не существует отдельно от прагматики. Прилагательное настоящий в русском языке имеет ряд оценочных значений: 'истинный' (настоящий кофе, настоящее золото), 'искренний, неподдельный' (настоящее сострадание), 'полностью соответствующий качеству чего-л.' (дать настоящую цену), 'представляющий собой полное подобие кого-, чего-л.' (девушка - настоящая русалка) (МАС, 2, с. 400-401). Настоящее не только должно соответствовать действительности, но и удовлетворять существующему аксиологическому идеалу: Одоевский поэт мира идеалъного, а не действительного (В. Белинский, $O$ русской повести и повестях Гоголя). «Идея означает, собственно говоря, некое понятие разума, а идеал - представление о сущем, адекватном какой-либо идее» 8 .

Признаком идеальности наделяется то, что существует налично и рядоположенно. В связи с представлением об идеале возникают многочисленные концепты. Так, в концептосфере русского языка выразительно представлен концепт настоящей дружбы и, соответственно, настоящего друга: Вот такой должна быть настоящая дружба! (В. Юрченко, Тринадцать сказок Дизеи). Это настоящая дружба! (Н. Гейнце, В тине адвокатуры). Ну вообще он действительно настоящий друг (В. Чемберджи, О Рихтере его словами). Вот что значит настоящий друг (Р. Гари, Свет женщины).

Не менее выразителен концепт настоящей любви: На то она $u$ первая любовь, Чтоб стала настоящею другая (Из песни). Это действительно настоящая любовъ, которая не за что-то, а, скорее, вопреки (А. Луковкина, Исцеление молитвами). Ох, настоящая любовъ - большое дело! (Н. Лесков, Обойденные). Да, это была любовь, настоящая любовъ, любовь со слезами $и$ радостями, любовь страстная (Ф. Достоевский, Неточка Незванова). Не вижу настоящей любви (А. Куприн, Гранатовый браслет).

Прагматика идеализированного настоящего опирается на идею единственности и неповторимости, которая согласуется с существующими механизмами идентификации. В отличие от

\footnotetext{
8 И. Кант, Критика чистого разума, пер. Н. Лосского сверен и отредактирован Ц.
} Арзаканяном и М. Иткиным, Москва 1994, с. 362. 
единичности, воплощающей смысл единого, единственное представляется тождественным («единственным по числу»). Идеальное должно быть одновременно и единственным: Так отциовский здравый смысл разруиил единственную настоящую любовь будущего писателя $и$ одновременно определил его творческую судъбу (Г.Р. Хаггард, Копи царя Соломона).

Тождество формы при различии величин даёт идею подобия. Оборот «как подобает» выражает требование соответствовать некоторым правилам: подобать «соответствовать принятым правилам, обычаям, чьему-л. положению»; подобающцй «такой, который требуется при данных обстоятельствах и т.п.; надлежащий (МАC, 3, 204), напр.: Он шел не торопясь, как и подобало посетителю музея (В. Катаев, Катакомбы). И хотя задолго до смерти он все собирался купить сапоги, чтобы явиться на суд, как подобает настоящему крестьянину, но все пропивал деньги, $u$ теперь стоял перед Тойоном, как последний якут, в дрянньх торбасииках... (В. Короленко, Сон Макара).

1.2. В концептосфере русского языка значительное место занимают гендерные представления. Языковая картина мира содержит не только понятие мужчины вообще, но и концепт «настоящего мужчины»9. Как следует из Словаря русского языка, мужчина - это не только «лицо, противоположное по полу женщине», но и «лицо мужского пола, отличающееся мужеством, твердостью» (MAC, 2, 309).

Тема мужчины всегда была актуальной и не перестаёт оставаться таковой до настоящего времени. Что значит - быть мужчиной? Каким должен быть настоящий мужчина? Что такое мужское достоинство? Эти и подобные им вопросы, затрагивающие тему мужского идеала, обсуждаются в бытовых, и не только, дискурсах: - Tы будущий мужчина. Настоящий мужсишна никогда не дерется сженцинами, это стыцно (В. Крапивин, Мальчик со шпагой). Ну что ж, верность это качество, достойное настояцего мужчины (В. Порутчиков,

\footnotetext{
9 Вслед за Ю.С. Степановым мы считаем концепт более объемным когнитивным конструктом человеческого сознания по сравнению с понятием. По выражению Степанова, концепт есть «некое суммарное явление, по своей структуре состоящее из самого понятия и ценностного (нередко образного) представления о нем человека» (Ю.С. Степанов, Константы. Словарь русской культуры. Опыт исследования. Москва 1997, c. 40-43).
} 
Гибель Царъграда). В его понимании все настоящие мужчижы должны были участвовать в этой войне (В. Крапивин, Острова и капитаны).

В концепте мужчины содержится представление о должном (подобающем), напр.: Сейчас, в эту минуту, я вижу его встречающим эту всем страшную, бессмысленную смерть на ногах, как подобает мужчине, более гордый, чем сама эта царица подземного царства, встречает он ее (Л. Андреев, Москва. Мелочи жизни). Товарищ мужчина, а все же заманчива долюсность твоя (Ю. Визбор). ${ }^{10}$ Согласно бытующему представлению настоящий мужчина должен в жизни сделать три вещи: построить дом, посадить дерево и вырастить сына.

В связи с существующими нравственными регламентациями возникает проблема права называться мужчиной. Так, чтобы быть мужчиной, нужно соответствовать ряду «уставных» признаков: Нельзя быть мужчиной, бойцом, и остаться кротким и мягким? (И. Тургенев, Накануне). ...Чичиков не первый красавец, но зато таков, как следует бъть мужчине, что будь он немного толще или полнее, уж это было бы нехорошо. Н. Гоголь, Мертвые души). Мужчинам? O, нет! Они гораздо свободнее; они могут быть тем, чем хотят, а мы бываем тем, чем нам велят (А. Писемский, Виновата ли она?).

Гендерная роль мужчины проявляется в мире возможностей: $\mathrm{Ha}$ Лазурном берегу загуляю и сбегу Где мужчина мой по имени «Могу» (И. Аллегрова). С идеей мужского могущества коррелирует экономическое представление о мужчине-хозяине, мужчинегосподине: - O мой хозяин, - продолжала она, - продай всю обстановку, которая имеется у тебя в доме, и живи на вырученные денъги (Сказки Шахерезады). - Не сердитесь на меня, мой господин. Женщины порой очень любопытны... (Н. Лакедемонская, Tы, я и тиран). «Дела Закона» (ап. Павел) с последующей славой и именитостью - удел и культурная роль мужчины.

С мужчиной связывается также идея счета, знака и значения напр.: Семъя-то большая, да два человека Всего мужиков-то: отец мой да $\boldsymbol{я}$ (Н. Некрасов, Крестьянские дети); ...а евших было около пяти тысяч человек, кроме женщзи и детей (Мф. 14:19).

10 «Мужчина - он должен...», а дальше по списку. 
Я думал идут двое, ан нет: мужик с бабой (Посл.). Ведъ $\boldsymbol{я}$ мужчина, $u$, клянусь - Немало это значит! (Ф. Шиллер, Достоинство мужчины).

Институт имени собственного также ассоциируется с мужчиной. Показательна в этом отношении дискурсивная практика некоторых народов. «У остяков и самоедов девки имен не имеют. Только когда замужем, то муж зовет „Баба”»11. Действенная мужская роль репрезентирована в мире причины и следствия. Мужчина «виновник»: Стал тесен девушке корсет - Понятно, $\boldsymbol{я}$ жс мужчина (Ф. Шиллер, Достоинство мужчины). Принадлежностью к категории мужчин объясняется многое: Караулов был добродетельный, даже целомудренный человек. Караулов любил графиню Конкордию, но Караулов бъл мужчина (Н. Гейнце, Тайна любви). Ну вот! великая беда, Что выпьет лишнее мужчина! (А. Грибоедов, Горе от ума).

Идея «быть мужчиной» (ср. нем ein Mann zu sein) проявляется в праве действовать, господствовать, подчинять окружающих собственной воле. В волеизъявление нередко подмешивается своеволие: - Своеволие! Это все, чем я могу в главном моменте показать непокорность и новую страшную свободу мою. Ибо она очень страшная. Я убиваю себя, чтобы показать непокорность и новую страшную свободу мою (Ф. Достоевский, Бесы) ${ }^{12}$.

Носителям русскоязычного дискурса часто приходится сталкиваться с динамической установкой относительно мужчины: Тяжело мне, доктор... - Пустяки, пустяки, идем! Будъте мужчиной, плюньте (А. Куприн, Молох). - Это я понимаю... Но будъ мужчиной... Призови, наконец, на помощь свое самолюбие... (Н. Гейнце, Дочь Великого Петра). Павлушка, будъте мужчиной. $Я$ вас не брошу в тюрьме. Прощай, прощай, моя квартира! (М. Булгаков, Зойкина квартира).

Афоризмы о мужчинах и женщинах, их взаимоотношениях в быту и браке составляют значительный фрагмент языковой картины мира. Репрезентированные в ней концепты «мужчина» и «женщина» отражают современные представления носителей русской культуры на фоне гендерных представлений, транслируемых из поколения

\footnotetext{
${ }^{11}$ В.А. Ивашко, Как выбирают имена, Минск 1980, с. 28.

12 Воля не должна быть имперсональной «своей» волей и служить насилию. Она собственная («чья»).
} 
в поколение. Гендерная лингвистика как научное направление изучает мужской гендер, понимаемый как конвенциональный конструкт, относительно автономный от биологического пола. Однако при исследовании многочисленных номинативных и фразеологических экспликаций концепта мужчины в языке нельзя не брать во внимание антиномию мужчины и человека.

\section{2. Принцип аутентичности. Феномен real man}

Известно, что во многих языках одно и то же слово обозначает как мужчину, так и человека вообще, например англ. man, фp. homme, рус. молодой человек (в апелляции к мужчине). В украинском языке «чоловіком» называют мужа: Терпилиха разом з чоловіком жили на Мазурівці в Полтаві, але він програвся... (І. Котляревський, Наталка Полтавка). С аналогичной ситуацией встречаемся и в белорусском языке: «чалавек 2. Разм. Муж; мужчына. Жанчына ведала нораў свайго чалавека: калі яму што ўбілася ў галаву, дык лепш не чапай, бо бяды не абярэшся (Сабаленка)» (ТСБМ, 5, 289)ํㅜㄹ. Современные гуманитарные науки объясняют факт «омужествления» человека проявлением андроцентризма - глубинной культурной традицией, сводящей субъективность к универсальной мужской норме ${ }^{14}$.

На наш взгляд, в когнитивных исследованиях концепта мужчины необычайно важно не смешивать институционально-гендерный план языка и его феноменологические аспекты. Очевидно, что мужчина как гендерная роль не то, что мужчина в статусе реального человека («real man»).

В свете феноменологии мужчина не концепт, а феномен (сущность). Сущностью называется то, благодаря чему нечто есть то, что оно есть ${ }^{15}$ жизнь есть жизнь, дети есть дети, мужчина есть мужчина и т. д. «Утверждение, что кто-то или что-то есть, относится

\footnotetext{
13 ТСБМ - Тлумачальны слоўнік беларускай мовы, ред. М.Р. Суднік, Мінск 1984.

${ }_{14}$ Словарь гендерньх терминов, http://a-z-gender.net/androcentrizm.html, [дата доступа: 14.01.2021].

15 Слову есть присущ феноменальный смысл небывалого и невозможного: «...to wieczne JEST, co ani było, ani będzie, ani może być, niepodległe wolnym wyborom, nieodstępne od najlepszości, nieludzko koniecznie» (A. Bańkowski, Etymologiczny słownik języka polskiego, Warszawa 2000, t. 1, s. 2.). Не существуя и никак себя не проявляя, сущность сама себя реально обнаруживает.
} 
к сущности лица или вещи, а не к его или ее видимости» ${ }^{16}$. Сущности обладают парадоксальным характером. Они есть, не существуя; феномены - «несуществующие сущности» (Э. Гессерль).

В слове «есть» звучит уверенность и сила: $A$ что, паны? - сказал Тарас, перекликнувшись с куренными. - Есть ещё̈ порох в пороховнццах? Не ослабела ли козацкая сила? Не гнутся ли козаки? - Есть ещё, батько, порох в пороховнццах. Не ослабела ещё козацкая сила; ещё не гнутся казаки! (Н. Гоголь, Тарас Бульба).

Уверенность - манифестация сознания, возникающая в ходе осознания несуществующей реальности. «Бог есть в силу того, что Его нет. Реальность Бога обусловлена тем, что в действительности он не существует» ${ }^{17}$ : Стало быть, тот бог есть же, по-вашему? - Его нет, но он есть. В камне боли нет, но в страхе от камня есть боль. Бог есть боль страха смерти (Ф. Достоевский, Старцы).

Подлинная сущность мужчины не проявляется в его действиях, но обнаруживается в поведении с другими. Только благодаря инстанции Другого (-их) достигается легитимность всего, что есть. В мире сущностей слово мужчиа не агентивная должность, а звание: Мужчины, мужчињь - Вы помните звание свое (Из песни), Это гордое звание - мужчина ${ }^{18}$. Присваиваемое звание - «своё» для мужчины. Мужская сущность требует не понимания, а признания со стороны других (ср. аномалию: самозванец).

Real man не относится к категории избранных. Его «своё» место, как и многих других званнъх, в жизненном мире - в жизни ${ }^{19}$. Под феноменом жизненного мира подразумевается повседневность в просцениуме «здесь», которую надо познавать «сейчас» и которая составляет основу для познания ${ }^{20}$. Жизненный мир человеческой повседневности складывается из суммы непосредственных очевидностей, выступающих ориентирами в поведении и не нуждающихся в утверждении и доказательстве. «Кто захочет задуматься над тем, что очевидно?! Очевидное коварно своей очевидностью. Роскошь очевидного в отсутствии необходимости

\footnotetext{
16 Э. Фромм, Иметь или быть? Ради любви кжизни, Москва 2004, с. 50.

${ }_{17}$ М. Веллер, Всё о жизни, Санкт-Петербург 2002, с. 221.

18 Ср.: профессор - звание, но может фигурировать как должность.

19 «... ибо много званых, а мало избранных» (Мф. 20:1).

20 Жизненный мир (нем. Lebenswelt) - понятие феноменологии Э. Гуссерля, предмет не естествознания, а феноменологии; мир (Umwelt), в котором мы живем, «почва и горизонт и теоретической, и внетеоретической практики» (Э. Гуссерль).
} 
проверять то, что очевидно». ${ }^{21}$ Жизненный мир - «свой» (близкий) для человека, но не собственный. В нем всё своё. В своём мире все и каждый пытаются жить, насколько это получается, своей жизнью.

Повседневность характеризуется поточностью (день проходит за днем) и глобальностью (Всё пройдет). Смысл слова всё близок к философской «усии» (сущности). Всё постигается через негацию «ничего» (всё и ничего, всё ничего, всего ничего). Всему проходящему присущ не только ход, но и негативный характер: (- Как всё прошло? - Ничего).

Очевидная реальность противопоставляется фактической данности (действительности). Последняя славится результатами в области материальной и духовной культуры. Для жизни характерен расцвет и увядание (ср.: плодоносить, но: процветать). При условии несуществования, культурный комформ дополняется роскошью цивилизации (жить в роскоши). «Ни одно создание не может достичь найвысшей степени своей натуры, если не перестанет существовать» (Фома Аквинский); ср.: жить и существовать («влачить жалкое существование»).

В реальности под названием «жизнь» мужчина не свидетель, а очевидец. Здесь в принципе ничего не должно происходить «по идее» (ср.: идеологизация жизни); всё само собой осуществляется «по сути». О «своём» человек не осведомлен (информирован). С ним он непосредственно знаком; в него его посвящают, ср.: осведомленный, но: ознакомленный (посвященный). В своем мире человеку нет необходимости как-то позиционировать себя и соблюдать дистанцию. Это мир близкого (очного) и далёкого (заочного) расстояния (ср.: соблюдать дистанцию, но: держать расстояние). В своём мире человек не является вариантом («одним из...»). Здесь он наедине с собою («сам-на-сам») или с другими. В своём мире нет места эгоизму и альтруизму: «надо жить не для себя и не для других, а со всеми и для всех» 22 . Комитативное (мы) здесь дополняется комиссивным «с кем»: Жил старик со своею старухой... (А. Пушкин).

Необходимость предметной идентификации и установления личности в реальности жизни сменяется потребностью аутентификации. Аутентичность осознается через феномен самости. «Самое

\footnotetext{
${ }^{21}$ Р. Полборн, Решение и выбор, Москва-Воронеж 2009, с. 9.

${ }^{22}$ Н.Ф. Федоров, Философия общего дела в 2 m., т. 1, Москва 2003, с. 359.
} 
главное это - сущность вещей, самость вещи, ее са́мое само́. Кто знает сущность, самое само вещей, тот знает все (...) что есть только вещь сама, самая сама и ничто другое?» 23 . Феномен самости принадлежит миру сущностей (сама натура, сама сущность, сама жизнь и др.). Аутентичное состояние переживается как чувство отречения от своей идентичности («Я не такой». «Я не такая»). Ср. бел. Народ то быў усё не такойскі: Сам Пушкін, Лермантаў, Жукоўскі I Гогаль шпарка каля нас Прайшлі, як павы, на Парнас (Тарас на Парнасе).

Доминантой многих характеризующих званий выступает элемент самый: Самый человечный человек. Санька же любил хвастать, что он самъцй храбрый, самъџй ловкий и вообще самъйсамъий (Е. Усачева, Рецепт кошмарного сна), ср.: звание «Самого сексуального и смешного мужчины», звание «самого привлекательного мужчины", звание «самого привлекательного мужчины года (Sexiest Man Alive).

Самость негативна (И сам ничего). В отличие от бытия, основанного на полагании и позитивности, сущность есть принцип негативный. Слова «ничего не меняется» подразумевают «то, что не меняется» - сущность. По формуле «не-А» осуществляется переход к негации антитезиса. Состояние подлинной самости высказывается словами «ни, ни» и генерально воплощается в пассаже «Ничего такого». Подлинность характерна для того, кто не допускает в своё поведение «ничего такого»: ни этого, ни этого, ни этого и т.д.

Негация не логическое отрицание явления, а противопоставленное видимости его обратное, ср. пол. negatywny (książk.) «odwrotny, przeciwstawny» (PSJP, 516)24. Осмысление мужчиной своей самости звучит, к примеру, в интенции: «Я мужчина еще жщчего...». Осознание своего превосходства нередко сопутствуется нарциссическим настроением: Да, $\boldsymbol{я}$ - мужмшна! Суть мою Вам лира доказала. [...]. Лицом подобен богу я И вынужден признаться, Что пью свободно из ручья, Где небеса струятся. [...] Да, $\boldsymbol{\Omega}$ мужчина! Кто другой С моей сравнится силой? Найдись такой пляши и пой И не робей, друг милый! (Ф. Шиллер, Достоинство мужчины).

\footnotetext{
23 А.Ф. Лосев, Самое само: https://omiliya.org/article/samoe-samo-a-f-losev, [дата доступа: 12.01.2021]. 24 PSJP - Popularny stownik języka polskiego, red. A. Markowski, Warszawa 2002, c. 516.
} 
Real man не первое лицо («Я»), а Сам: - Как здоровъе, как сам? (Разг.). - А ты сама? Твоя-то жизнъ, где же (А. Арбузов, Иркутская история). Имперсональное «Сам» - титул того, кто, по сути, не должен ничего чинить - не проявлять самочинства: ни судить (не заниматься самосудом), ни проявлять волю (не самовольничать), ни любить (не быть самолюбивым). Сам не деятель и участник, а источник. Титул «Сам» приписывается Богу (Сам Бог) и людям верхнего эшелона власти: Спивак допрашивал не ротмистр, а сам генерал (М. Горький, Жизнь Клима Самгина). Это также титул людей искусства, владеющих публикой, и других «власть имеющих»: Наш незаметный Пъер смеет любить, да еще кого, саму Ольгу Сур, первую артистку циика (А. Куприн, Ольга Сур). Самость акцентируется в церемонии чествования. Обладать титулом «самого» для мужчины - честь.

Слово самъй не имеет внешней референции. «Размышления над самим собой в виде объективирующего понимания не схватывает самой самости, которая от этого понимания ускользает и в своей неосязаемой суверенности противопоставляет себя всему известному и объясненному» 25 . Рационально необъяснимая сущность на поверку оказывается несомненной в своей очевидности. «Самый» хотя, случается, и бывает «сам по себе» (взятый в отдельности, как таковой), однако его интимная сущность феноменальная - для кого «самый» («самый-самый»): Он самъй-самъий страшный в лесу? (А. Зиборов, Страна чудес). Как для меня, то ты самъий-самый глупый на свете идиот и балбес (А. Буторин, Осада рая). Ты самъй красивый, самъй

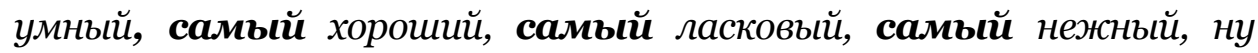
в общем самъй-самъй (Т. Нелюбина, Мой дом на Урале).

Непроявленная аутентичность манифестируется самой реалией и обнаруживается теми, кто находится в зоне ее презентации. Са́мое само́ не передается концептуальным знанием, а высказывается мнением; мнить - 'думать': Я мнил, что грубый ты и гордый человек (А. Островский, Козъма Захарьич Минин, Сухорук); ср.: мниться 'думается'; много (или высока) мнить о себе - быть о себе слишком высокого мнения (MAC, 2, 280). В отличие от знания, мнение не существует в форме «как», но есть: У каждого есть свое мнение. Есть мнение, что поэзия развилась из древних магических

\footnotetext{
25 См.: Б. Вышеславцев, Этика преображенного эроса, Москва 1994, с. 264.
} 
заклинаний. Мнение не подлежит дискуссии, однако, случается, оспаривается: Некоторые оспаривали его мнение, некоторые защищали его (Л. Толстой, Война и мир).

Самость не является свойством настоящего мужчины. Это сущностная характеристика реального мужчины-человека, воплощенная и звучащая в отзывах («отзвуках») других (ср.: свойственный кому, но: характерный для кого). Аналогия постижения аутентичности усматривается в феномене эха. Презентация мужской сущности проходит в критических отзывах - мнениях о нем: Именно поэтому самый-самый мужчина - это нет, не зануда, а уверенный в себе мужчина, твёрдый, мужчина с множеством жестких границ (Л. Вебер, Доверие внутреннему мужчине) ${ }^{26}$; ср.: Мужчина - хам, зануда, деспот, мучитель, скряга и тупица; чтоб это стало нам известно, нам просто следует жениться (И. Губерман).

Характеристические элементы языка не предназначены выполнять функцию идентификации. В них отсутствует опосредованное позитивное «как». Прозвучало бы странно Вы как человек... (Почему «как»?). Человек - присвоенное референту звание. В ком-то узнают человека, другого этим званием обходят. В буквальном и фигуральном смыслах, аутентификация «званных» не является их понятийной дифференциацией. С ними знакомятся, их познают и распознают. В ходе познания не выбирают, однако отдают предпочтение кому-чему-либо превосходящему.

Человек распознается по полу. По сути, пол не является различным (мужским или женским); пол - разный (разнополые дети, разнополые близнецы). И только «по идее» (в актах размножения) актуализируется момент дифференциации (можно сказать, что та или иная особъ принадлежит к мужскому или женскому полу). В отличие от различия, разность (рознь) не существует, но есть для кого: Неужели и правда думала, что для меня есть разница - вампир она или нет? (Е. Коути, Длинная серебряная ложка). Это область сомнений человека: - Разве есть разница... (Н. Гейнце, В действующей армии). Разница отсутствует в состоянии, проходящем под рубрикой «абы» (без разницы): абы с кем, абы-где, абы-как и т.д. В этике подобное состояние - блуд, в поведении - блудняк (жарг.), в познании - заблуждение.

${ }^{26}$ Ср.: Советский псих - самый нормальный в мире (Ф. Искандер). 
В мужской сущности не убеждаются, но удостоверяются. Нота сомнения звучит, например, в слове разве: Кто любую звал голубкой И за каждой бегал юбкой Разве тот - мужчина? Кто готов подать нам стремя И предать нас в тоже время Разве тот мужчина? Тот - МУЖЧИНА, кто отважен И душою НЕ продажен!!! Толъко тот - мужчина! (М. Магомаев).

В жизненном мире концепты «мужчина» и «женщина» сменяются реалиями мужик и баба. С церемонией распознания по полу встречаемся у Н. Гоголя:

У одного из строений Чичиков скоро заметил какую-то фигуру, которая начала вздорить с мужиком, приехавшим на телеге. Долго он не мог распознать, какого пола была фигура: баба или мужик. Платье на ней было совершенно неопределенное, похожее очень на женский капот, на голове колпак, какой носят деревенские дворовые бабы, только один голос показался ему несколько сиплым для женщины. «Ой, баба! - подумал он про себя и тут же прибавил: - ой, нет!» - «Конечно, баба!» - наконец сказал он, рассмотрев попристальнее. (...) По висевшим у ней за поясом ключам и по тому, что она бранила мужика довольно поносными словами, Чичиков заключил, что это, верно, ключница (Н. Гоголь, Мертвые души).

Признаки «мужской - женский» образуют гендерную оппозицию, маркированным членом в которой является признак «мужской». Слова мужик и баба такой системной оппозиции не создают; они составляют пару. Элементы пары - антиподы. Принцип антиподности осознается в словах-ориентирах «над» и «под», «верх» и «низ», «левый» и «правый» и др. «Верх есть то, что не есть низ; определение верха заключается только в том, чтобы не быть низом, и первое есть постольку, поскольку есть его антипод, и наоборот» 27. С аналогичным «небытием» встречаемся и в ходе осмысления пола: мужик есть тот, кто не есть баба - не-баба. Слова «Не будь бабой» - не стимул, а посылаемая наставительная интенция (импульс). Сущность реалий жизненного мира постигается путем негации. Как быть разумным? - Не быть дураком. Таких, как он много еще найдешь! Не будъ дурой, не будъ дурой! Не будъ дурой, не будъ дурой! (Из песни).

27 В.И. Ленин, Философские тетради, Москва 1978, с. 127. 
Благодаря принципу антиподности обнаруживается аспект земного и возвышенного. Возвышаясь над своей тварной природой, человек преодолевает периоды дикости и варварства, достигает стадии цивилизации. Мужская «приземленность» звучит в характеристиках типа мужик, мужлан 'о грубом, невежественном человеке' - Bы мужкк. Грубый медведъ! (А. Чехов, Медведъ): - Мужллан ты сиволапъй! (П. Мельников-Печерский, В лесах) и др. Критическое начало языка воплощается в словах, отмечающих несовершенство кого-чего-либо. Градация по принципу «над» («верх») и «под» («низ») получает языковое воплощение в феномене обзывания: Дурак. - Сам дурак (Разг.). Дурачина ты, простофиля! Не умел ты взять выкупа с рыбки! Хоть бы взял ты с нее корыто (А. Пушкин).

Принцип антиподности не имеет отношения к логической классификации и закону достаточного основания. Цивилизованность как стадия общественного развития характеризуется присутствием общественных cmpam (слоев, сословий, групп). Реалии стратифицируются (от лат. stratum и facio, буквально «расслаивание») и ранжируется по принципу «выше-ниже». Низшее (холопское) сословие противопоставляется дворянскому сословию (ср.: бел.: мужыцкае и панскае). Стратификация осуществляется по принципу предпочтения (пол. wyróżnienie), где не видится тождество и различие, однако замечается сходство и разница. Так, «wyróżniać płaszczyzny» (пол.) не значит выделять различные категории (классы, разряда и т.п.). В паре «мужик-баба» верховенствует мужское начало: - Год уже как нет со мной человека моего. Некому покомандовать мною... (Из разг.). Мужик тянет в одну сторону, баба в другую $(\text { Погов. })^{28}$. Ситуация «ходить под бабой» мужским полом, в принципе, не приветствуется.

Парность не единство противоположностей, а единение начал -

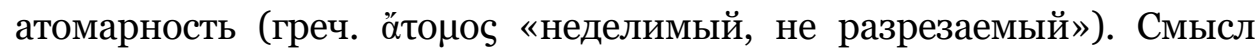
неделимости («единого целого») повсеместно присутствует в паремиях на тему «мужик и баба»: Мужик без бабы пуще мальх деток сирота. Мужик без жены что гусь без воды и др. Пара не собирательная категория (двое), а множество, кратное двум (вдвоем). Элемент -крат- происходит от праслав. *kortъ («раз») - ст.-слав. съто

${ }_{28}$ В. Даль, Толковый словарь живого великорусского языка, т. 1, Москва 1996, с. 65. 
кратъ, сербохорв., двакрат, трикрат, чешск. krát «раз», польск. kroć (dwakroć, trzykroć). Смысл кратности («разовости») в неповторимости и незавершенности: Еще раз - не значит 'повторить'. Не случайны в «крат» (демократ, бюрократ и т.д.) смыслы «сила, власть». На кратность указывают древние сочетаниях типа самдруг - вдвое, вдвоем; сам-третей - втрое, втроем: За стол он садился всякий день сам-двадцать, по случаю непомерного количества дочек, племянниц и других сирот родственниц (М. СалтыковЩедрин, Губернские очерки).

В парной кратности доминирует холистический аспект единения: Надо уйти ото всего, забыться, побыть сам-друг с природой (В. Шишков, Угрюм-река). Элементы пары не согласуются (соответствуют), а подходят один к одному - сходятся или расходятся в своих характеристиках ${ }^{29}$. Вопрос «На что похоже?» ориентирован на поиск аналогии. Путем аналогии познается аутентичность изначальная подлинность всего, допускающего разночтение и преференцию.

\section{Заключение}

Аутентичность - поведенческая характеристика человека и путь его самопознания через принятие на себя обязательств перед другими и отказа от должного, т.е. различных социальных ролей. Гендерные институциональные представления о мужчине как деятеле служат утверждению существующих в различных обществах гендерных ролей и правовых отношений равенства или неравенства, укрепляющего языковой андроцентризм. Институциональным «измам» противопоставляются реальные мужское и женское начала, не имеющие позитивного «как», не подчиняющиеся закону тождества, установленным правилам и нормативно-культурным регламентациям. В свете феноменологии мужское и женское не различается существенными признаками, но разнится своими сущностными характеристиками и ранжируется по принципу превосходства («верхниз»). Антиномия идентичности и аутентичности обнаруживается в концептуализации действитель-ности и в осознании самой реальности.

29 Ср. мотивацию развода: «Не сошлись характером». 


\section{Список сокращений}

МАС - Словарь русского языка в 4 m., под ред. А.П. Евгеньевой, Москва 1981 - 1984.

ТСБМ - Тлумачальны слоўнік беларускай мовы, ред. М. Р. Суднік, Мінск 1984.

PSJP - Popularny stownik języka polskiego, red. A. Markowski, Warszawa 2002.

\section{Литература}

Аристотель, Метафизика, [в:] Антология мировой философии в 4-х т., т. 1, Москва 1969.

Бенвенист Э., Общая лингвистика, Москва 1974.

Веллер М., Всё о жизни, Санкт-Петербург 2002.

Вышеславцев Б., Этика преображенного эроса, Москва 1994.

Даль В., Толковый словарь живого великорусского языка, т. 1, Москва 1996.

Декарт Р., Сочинения в 2 m. Перевод с лат. и франц., сост., ред., вступ. ст. В.В. Соколова, т.1, Москва 1989.

Ивашко В.А., Как выбирают имена, Минск 1980.

Кант И., Критика чистого разума, перевод Н. Лосского сверен и отредактирован Ц. Арзаканяном и М. Иткиным, Москва 1994.

Ленин В.И., Философские тетради, Москва 1978.

Лосев А.Ф., Бытие - имя - космос, Москва 1993.

Лосев А.Ф. Самое само, https://omiliya.org/article/samoe-samo-a-f-losev, [дата доступа: 12.01.2021].

Мамардашвили М.К., Психологическая топология пути. М. Пруст «В поисках утраченного времени», Санкт-Петербург 1997.

Полборн Р., Решение и выбор, Москва-Воронеж 2009.

Словарь гендерных терминов, http://a-z-gender.net/androcentrizm.html, [дата доступа: 14.01.2021].

Степанов Ю.С., Константы. Словарь русской культуры. Опыт исследования, Москва 1997.

Федоров Н.Ф., Философия общего дела в 2 т., т.1, Москва 2003.

Фромм Э., Иметь или быть? Ради любви к жизни, Москва 2004.

Bańkowski A., Etymologiczny stownik języka polskiego, t.1, Warszawa 2000.

\section{References}

Aristotel', Metafizika, [v:] Antologiâ mirovoj filosofii v 4-h t., t. 1, Moskva 1969.

Benvenist È., Obŝâ̂ lingvistika, Moskva 1974.

Veller M., Vsë o žizni, Sankt-Peterburg 2002. 
Vyšeslavcev B., Ėtika preobražennogo èrosa, Moskva 1994.

Dal' V., Tolkovyj slovar' živogoveliko russkogo âzyka, t. 1, Moskva 1996.

Dekart R., Sočineniâ $v 2$ t., Perevod s lat. i franc., sost., red., vstup. st. V.V. Sokolova, t. 1, Moskva 1989.

Ivaško V.A., Kak vybiraût imena, Minsk 1980.

Kant I., Kritika čistogo razuma, perevod N. Losskogo sveren i otredaktirovan C. Arzakanânom i M. Iperevod, Moskva 1994.

Lenin V.I., Filosofskie tetradi, Moskva 1978.

Losev A.F., Bytie - imâ - kosmos, Moskva 1993.

Losev A.F. Samoe samo, https://omiliya.org/article/samoe-samo-a-f-losev, [data dostupa: 12.01.2021].

Mamardašvili M.K., Psihologičeskaâ topologiâ puti. M. Prust «V poiskah utračennogo vremeni», Sankt-Peterburg 1997.

Polborn R., Rešenie i vybor, Moskva-Voronež 2009.

Slovar' gendernyh terminov, http://a-z-gender.net/androcentrizm.html, [data dostupa: 14.01.2021].

Stepanov Û.S., Konstanty. Slovar' russkoj kul'tury. Opyt issledovaniâ, Moskva 1997.

Fedorov N.F., Filosofiâ obŝego dela $v 2$ t., t. 1, Moskva 2003.

Fromm È., Imet' ili byt'? Radi lûbvi k žizni, Moskva 2004.

Bańkowski A., Etymologiczny stownik języka polskiego, t. 1, Warszawa 2000. 